Vol.59: e16160439, January-December 2016 http://dx.doi.org/10.1590/1678-4324-2016160439 ISSN 1678-4324 Online Edition
BRAZILIAN ARCHIVES OF BIOLOGY AND TECHNOLOGY

AN INTERNATIONAL JOURNAL

\title{
A comparison of efficiency parameters of SSR markers and genetic diversity analysis in Amorphophallus paeoniifolius (Dennst.) Nicolson
}

\author{
Rupsanatan Mandal ${ }^{1}$, Sumita $\mathrm{Nag}^{2}$, Jayanta Tarafdar $^{3}$, Surajit Mitra ${ }^{3}$. \\ ${ }^{1}$ Uttar Banga Krishi Viswavidyalaya - Genetics and Plant Breeding, Pundibari, West Bengal, India; ${ }^{2}$ Ramakrishna \\ Mission Vivekananda University - Agricultural Biotechnology, Kolkata, West Bengal, India; ${ }^{3}$ Bidhan Chandra \\ Krishi Viswa Vidyalaya - AICRP on Tuber Crops, Nadia, West Bengal, India.
}

\begin{abstract}
Amorphophallus (elephant foot yam) is an herbaceous edible aroid crop which belongs to the family Araceae. The study was undertaken to identify the efficient SSR primer that could differentiate a set of 12 elephant foot yam genotypes. Various efficiency parameters, namely, Polymorphism Information Content (PIC), Marker Index (MI), Resolving Power (RP) and Diversity Index (DI) were studied for 11 primers. The relationship between the parameters was studied using Spearman rank correlation coefficient. Discrimination analysis was done to find out the most effective parameter. Finally Principal Coordinate Analysis (PCoA) and dendrogram was done to find out the genetic diversity among the germplasm. The SSR markers under this investigation will facilitate further studies in population genetics and utilization of A. paeoniifolius.
\end{abstract}

Key words: Elephant foot yam, Marker Index, Discrimination analysis and Principal coordinate analysis.

\footnotetext{
*Authors for correspondence: rup.biotech@gmail.com
} 


\section{INTRODUCTION}

Amorphophallus (Elephant foot yam) is a genus of perennial plants belonging to Araceae family [ $\left.{ }^{1}\right]$. This genus includes more than 170 species, which are mainly distributed in the tropics or subtropics of West Africa and South Asia $\left[{ }^{2}\right]$. It contains glucomannan (a water-soluble dietary fiber), which helps to reduce lipids, systolic blood pressure and glycemia in human $\left[{ }^{3,4}\right]$. It is a rich source of dietary fiber and have low glycemic index which helps in the treatment of heart ailments as well as diabetes. It is also helpful in regulating the good cholesterol level in the body due to presence of high amount of omega fatty acids. It is low in fat contain and is only shown to have the essential fatty acids that help in reducing the risks of obesity and diseases associated with it [5]. Amorphophallus paeoniifolius (Dennst.) Nicolson is widely distributed and cultivated in India, Indonesia and other Asian countries. It has large variation in petiole colour, such as light to dark green, blackish green, gray, reddish or pinkish white. On the basis of petiole structure it may be classified into two groups A. campanulatus (A. paeoniifolius) var. hortensis (smooth petiole) and A. campanulatus (A. paeoniifolius) var. sylvestris (rough petiole) $\left.{ }^{6}\right]$. Elephant Foot Yam producing states in India are Andhra Pradesh, West Bengal, Gujarat, Kerala, Tamil Nadu, Maharashtra, Uttar Pradesh, and Jharkhand. The net economic profit is over 1 lakh rupees per ha in India from this cultivation $\left[^{7}\right]$. Thus it has the great potentiality to provide nutritional security to the developing countries along with their medicinal aspects. Research exploring molecular genetics of elephant foot yam is limited till date. However, few genomic molecular makers have been developed for this crop. SSR markers have been shown to be an effective tool to carry out germplasm characterization and genetic diversity studies in crop species $\left[^{8,9,10,11,12}\right]$. Hence in-depth studies based on molecular markers like SSRs will help definitely in understanding the genetic diversity of germplasm as well as identification, conservation and utilization of this crop. Our study was initiated to access the utility of SSR markers in differentiating some Indian elephant foot yam accessions to identify markers that could be useful for future genetic mapping and improvement programs.

\section{MATERIALS AND METHODS}

In this study, a representative set of 12 accessions of elephant foot yam (Table 1) collected from the different parts of India were used for analyzes.

Table-1: List of twelve Elephant foot yam accessions

\begin{tabular}{|l|l|l|}
\hline Sl. No. & Germplasm & Source \\
\hline 1 & CTCRI-1 & CTCRI, Kerala \\
\hline 2 & NDA-9 & NDUAT, Faziabad \\
\hline 3 & BCA-7 & BCKV,West Bengal \\
\hline 4 & Gajendra & APAU, Hyderabad \\
\hline 5 & Ranchi & BAU, Ranchi \\
\hline 6 & BCA-3 & BCKV,West Bengal \\
\hline 7 & NDA-5 & NDUAT, Faziabad \\
\hline 8 & BCA-2 & BCKV,West Bengal \\
\hline 9 & CTCRI-2 & CTCRI, Kerala \\
\hline 10 & IGAM-2 & IGAU, Raipur \\
\hline 11 & BCA-5 & BCKV,West Bengal \\
\hline 12 & Sree Padma & CTCRI, Kerala \\
\hline
\end{tabular}

Total genomic DNA was extracted from the young leaves of each genotype following the standard cetyltrimethylammonium bromide (CTAB) method with some modifications $\left[{ }^{13}\right]$. The quality and quantity of the extracted DNA was verified on 1\% TBE agarose gels. All DNA extracts were stored at $-20^{\circ} \mathrm{C}$. A total of $13 \mathrm{SSR}$ primer pairs developed from Amorphophallus konjac $\left[{ }^{14}\right]$ were screened and tested. Among the 13 SSR primer pairs (Table-2), 11 were chosen and used in this study based on their reliable amplification profiles, high polymorphism and the ease with which the results could be unambiguously read and scored. 
Genetic diversity analysis in Amorphophallus sp.

Table-2: List of thirteen SSR primers and their efficiency parameters

\begin{tabular}{|c|c|c|c|c|c|c|c|c|c|}
\hline $\begin{array}{l}\text { Locu } \\
\mathrm{s}\end{array}$ & Primer sequence $\left(5^{\prime}-3^{\prime}\right)$ & $\begin{array}{l}\mathbf{T}_{\mathrm{a}} \\
\left({ }^{\circ} \mathbf{C}\right. \\
)\end{array}$ & $\begin{array}{l}\text { GenBan } \\
\text { k } \\
\text { accession } \\
\text { No. } \\
\end{array}$ & $\begin{array}{l}\text { NT } \\
\text { B }\end{array}$ & $\begin{array}{l}\mathbf{N P} \\
\mathbf{B}\end{array}$ & $\begin{array}{l}\text { PI } \\
\text { C }\end{array}$ & MI & DI & $\mathbf{R P}$ \\
\hline $\begin{array}{l}\text { Amo } \\
\text { r } 22\end{array}$ & $\begin{array}{l}\text { F: AATTAGAGGTGAATAGGGAGG } \\
\text { R: AAGTATTGATAAAAGTTTGCCA }\end{array}$ & 60 & $\begin{array}{l}\text { JF71059 } \\
4\end{array}$ & 4 & 4 & $\begin{array}{l}0.4 \\
9 \\
\end{array}$ & $\begin{array}{l}3.0 \\
6 \\
\end{array}$ & $\begin{array}{ll}0.7 \\
7\end{array}$ & $\begin{array}{l}3.5 \\
0\end{array}$ \\
\hline $\begin{array}{l}\text { Amo } \\
\text { r } 33\end{array}$ & $\begin{array}{l}\text { F:TTAAGTATTGAACATCTGATGTACT } \\
\text { C } \\
\text { R: AATGCTCCACTATGACGTGA }\end{array}$ & 58 & $\begin{array}{l}\text { JF71059 } \\
5\end{array}$ & - & - & - & - & - & - \\
\hline $\begin{array}{l}\text { Amo } \\
\text { r } 34\end{array}$ & $\begin{array}{l}\text { F: GTGGGGAGTGGAGGTGGTTG } \\
\text { R: } \\
\text { GAGATTCCATTAGTTGGGTGAGAAA }\end{array}$ & 60 & $\begin{array}{l}\text { JF71059 } \\
6\end{array}$ & 3 & 2 & $\begin{array}{l}0.2 \\
2\end{array}$ & $\begin{array}{l}1.1 \\
6\end{array}$ & $\begin{array}{l}0.5 \\
8\end{array}$ & $\begin{array}{l}1.8 \\
3\end{array}$ \\
\hline $\begin{array}{l}\text { Amo } \\
\text { r 36 }\end{array}$ & $\begin{array}{l}\text { F: CCACCCCTCACCGACAG } \\
\text { R: TCCTTCAATTTCACATCCTTCT }\end{array}$ & 254 & \begin{tabular}{l|l} 
JF71059 \\
7
\end{tabular} & 4 & 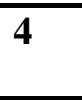 & $\begin{array}{ll}0.3 \\
1\end{array}$ & $\begin{array}{ll}3.3 \\
7\end{array}$ & $\begin{array}{ll}0.8 \\
4\end{array}$ & $\begin{array}{ll}1.8 \\
3\end{array}$ \\
\hline $\begin{array}{l}\text { Amo } \\
\text { r } 41\end{array}$ & $\begin{array}{l}\text { F: GGTTGCACAGGCTCAGATTGT } \\
\text { R: GACGGGCTCCCTATGTCCAC } \\
\end{array}$ & 58 & $\begin{array}{l}\text { JF71059 } \\
8\end{array}$ & 3 & 2 & $\begin{array}{ll}0.3 \\
0\end{array}$ & $\begin{array}{ll}0.9 \\
6\end{array}$ & $\begin{array}{l}0.4 \\
8\end{array}$ & $\begin{array}{ll}1.3 \\
3\end{array}$ \\
\hline $\begin{array}{l}\text { Amo } \\
\text { r } 43\end{array}$ & $\begin{array}{l}\text { F: GGGAGTCTTGGGAGGTGAAA } \\
\text { R: AAATTTGAGCCATTGAGTGCA }\end{array}$ & 54 & $\begin{array}{l}\text { JF71059 } \\
9\end{array}$ & 5 & 3 & $\begin{array}{ll}0.1 \\
8\end{array}$ & $\begin{array}{l}1.5 \\
1\end{array}$ & 0.5 & $\begin{array}{l}1.6 \\
7\end{array}$ \\
\hline $\begin{array}{l}\text { Amo } \\
\text { r } 46\end{array}$ & $\begin{array}{l}\text { F: CGTCCACCCCTCACTAAACCCG } \\
\text { R: CGCCTGCGTGCGGTCGTAT }\end{array}$ & 60 & $\begin{array}{l}\text { JF71060 } \\
\text { O }\end{array}$ & 2 & 2 & $\begin{array}{l}0.5 \\
0\end{array}$ & 1.5 & $\begin{array}{l}0.7 \\
5\end{array}$ & $\begin{array}{l}2.0 \\
0\end{array}$ \\
\hline $\begin{array}{l}\text { Amo } \\
\text { r 51 }\end{array}$ & $\begin{array}{l}\text { F: TTAATGAGGTGGTTGGGAGGT } \\
\text { R: AAGCAAAATTTGAGCCATTGA }\end{array}$ & 60 & $\begin{array}{l}\text { JF71060 } \\
1\end{array}$ & 10 & 8 & $\begin{array}{ll}0.2 \\
2 \\
\end{array}$ & $\begin{array}{l}3.8 \\
9\end{array}$ & $\begin{array}{l}0.4 \\
9 \\
\end{array}$ & $\begin{array}{l}3.1 \\
6 \\
\end{array}$ \\
\hline $\begin{array}{l}\text { Amo } \\
\text { r 53 }\end{array}$ & $\begin{array}{l}\text { F: TAAGGTGATTCGGTTGCAAAT } \\
\text { R: TTTGTGTGCATGTGTTGTGAA }\end{array}$ & 54 & $\begin{array}{l}\text { JF71060 } \\
2\end{array}$ & 3 & 2 & $\begin{array}{ll}0.1 \\
0\end{array}$ & $\begin{array}{ll}0.7 \\
7\end{array}$ & $\begin{array}{ll}0.3 \\
8\end{array}$ & $\begin{array}{ll}0.3 \\
3\end{array}$ \\
\hline $\begin{array}{l}\text { Amo } \\
\text { r 54 }\end{array}$ & $\begin{array}{l}\text { F: CAGATCCAGATGCAACCCTAA } \\
\text { R: TCCGCTCAGTATCTGACCATT }\end{array}$ & 60 & $\begin{array}{l}\text { JF71060 } \\
3\end{array}$ & 5 & 3 & $\begin{array}{ll}0.1 \\
0\end{array}$ & $\begin{array}{l}0.7 \\
9\end{array}$ & $\begin{array}{ll}0.2 \\
6\end{array}$ & $\begin{array}{ll}0.5 \\
0\end{array}$ \\
\hline $\begin{array}{l}\text { Amo } \\
\text { r 55 }\end{array}$ & $\begin{array}{l}\text { F: TAGGACCTAGGCATCGAGGAT } \\
\text { R: TTAAGGACGTGGCAGTGAGA } \\
\end{array}$ & 54 & $\begin{array}{l}\text { JF71060 } \\
4\end{array}$ & - & - & - & - & - & - \\
\hline $\begin{array}{l}\text { Amo } \\
\text { r } 57\end{array}$ & $\begin{array}{l}\text { F: GATGGAGTTGTGACTCCGTGT } \\
\text { R: GAGGCCTTGCCTCAAACTACT } \\
\end{array}$ & $\mathbf{5 0}$ & $\begin{array}{l}\text { JF71060 } \\
5 \\
\end{array}$ & 3 & 3 & $\begin{array}{ll}0.2 \\
5 \\
\end{array}$ & $\begin{array}{l}2.0 \\
4 \\
\end{array}$ & $\begin{array}{l}.6 \\
8 \\
\end{array}$ & $\begin{array}{l}1.0 \\
\mathbf{0}\end{array}$ \\
\hline $\begin{array}{l}\text { Amo } \\
\text { r } 58\end{array}$ & $\begin{array}{l}\text { F: AAGAAGGGTGATTAGGGAGGA } \\
\text { R: TTAAACCCTCAAGTATTCTCTCTC }\end{array}$ & $\mathbf{5 0}$ & $\begin{array}{l}\text { JF71060 } \\
6\end{array}$ & 2 & 1 & .08 & $\begin{array}{l}0.4 \\
9\end{array}$ & $\begin{array}{l}0.4 \\
9\end{array}$ & $\begin{array}{l}0.1 \\
7\end{array}$ \\
\hline
\end{tabular}

$\left[\mathrm{T}_{\mathrm{a}}\right.$ : Annealing Temperature; NTB: Number of Total Band; NPB: Number of Polymorphic Band; PIC: Polymorphism Information Content; MI: Marker Index; DI: Diversity Index; RP: Resolving Power]

PCR amplifications were performed in $25 \mu 1$ reaction mixtures containing $1 \mathrm{U}$ Taq polymerase (Biotools), $2.5 \mu \mathrm{l}$ 10X PCR buffer, $1 \mu \mathrm{l} 2.5 \mathrm{mM}$ of each dNTPs, $1 \mu 110 \mu \mathrm{M}$ of each forward and reverse primer and approximately $10 \mathrm{ng}$ genomic DNA. Cycling conditions were $5 \mathrm{~min}$ at $94^{\circ} \mathrm{C}$, followed by 35 cycles of $45 \mathrm{~s}$ at $94^{\circ} \mathrm{C}, 45 \mathrm{~s}$ annealing at $50^{\circ}-60^{\circ} \mathrm{C}$, a $1 \mathrm{~min}$ extension at $72^{\circ} \mathrm{C}$ and a final extension step of $2 \mathrm{~min}$ at $72^{\circ} \mathrm{C}$. The locus-specific annealing temperatures were presented in Table-2. Final PCR products were resolved on a $1.5 \%$ agarose gel and visualized by Ethidium Bromide (Figure-1). 


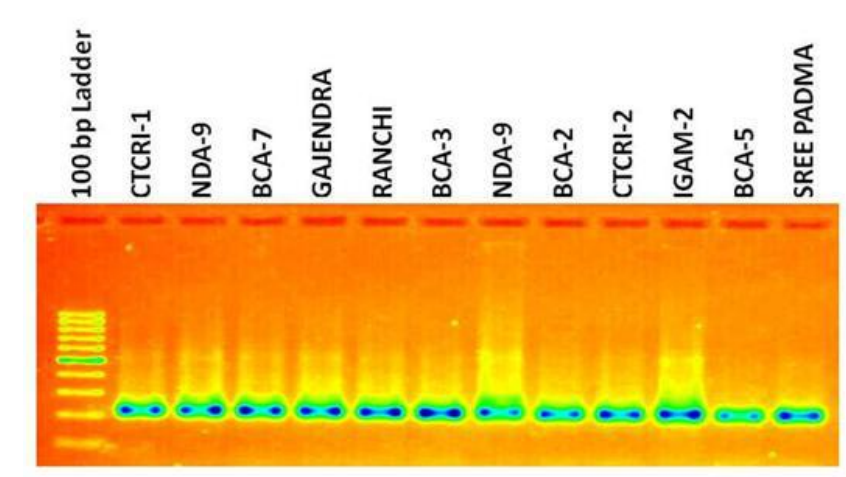

Amor- 46

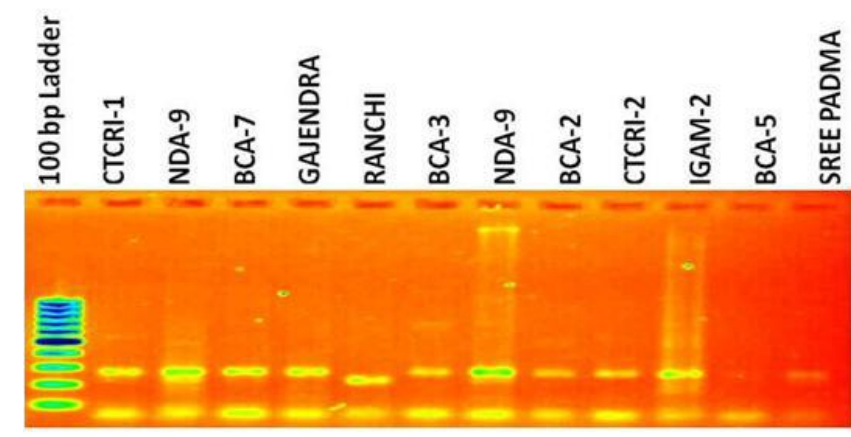

Amor- 57

Figure-1: Agarose gel picture of four important primers

Product sizes were determined by comparison to a $100 \mathrm{bp}$ DNA ladder (Biotools). To determine the most informative primer, following parameters were calculated: Polymorphism Information Content (PIC), Marker Index (MI), Resolving Power (RP), and Diversity Index (DI) [ $\left.{ }^{15}\right]$. PIC for the SSRs marker was estimated by using the formula $\operatorname{PIC}_{i}=2 f_{i}\left(1-f_{i}\right)$. Where, $f_{i}$ is the frequency of the marker fragments that were present $\left(1-f_{i}\right)$ is the frequency of the marker fragments that were absent. MI was calculated as: MI = PIC $\mathrm{x}$ number of polymorphic loci. RP is defined per primer as: $\mathrm{RP}=\Sigma \mathrm{Ib}$, were " $\mathrm{I}_{\mathrm{b}}$ " is the band informativeness, that takes the values of 1-[2 X (|0.5-pl)], being " $p$ " the proportion of each genotype containing the band. The diversity index, which indicates the genetic diversity of the germplasm, was calculated using the formula $D I=1-1 / L \Sigma P_{i}^{2}$, in which $P_{i}$ is the allele frequency in (each individual allele is considered a unique fragment amplification) and $\mathrm{L}$ is the number of loci. The relationship between the efficiency parameters was analyzed by calculating the Spearman rank correlation $\left[{ }^{16}\right]$. Presence or absence of the band was scored as 1 or 0 , respectively, obtaining the molecular identification profile for each individual $\left[{ }^{17}\right]$. A dendrogram was

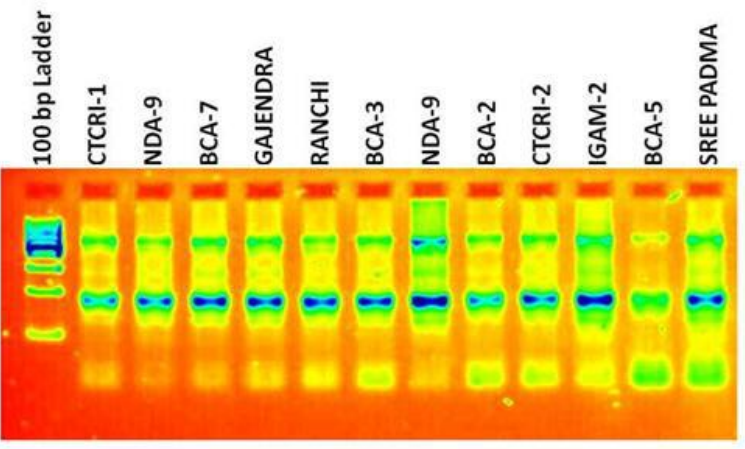

Amor- 22

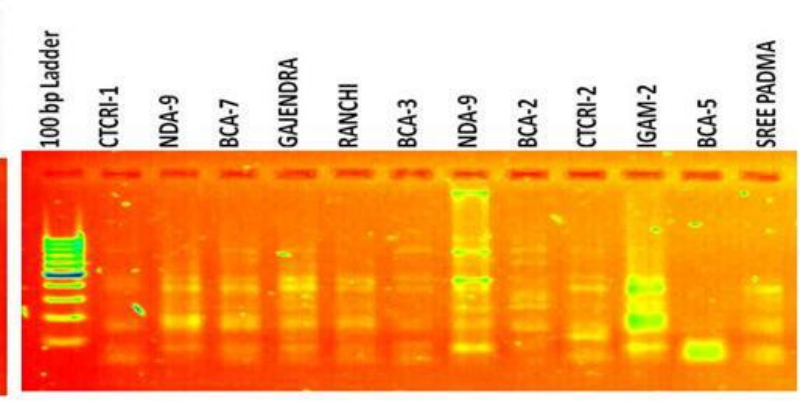

Amor- 51

constructed using the Dice similarity coefficient (DSC) $\left[{ }^{18}\right]$, the unweighted pair group method with arithmetic average (UPGMA), and the jackknife method for corroboration. All calculations were performed using NTSYS PC version $2.2\left[{ }^{19}\right]$ and Moreover, a principal coordinate analysis (PCoA), using the DSC $\left[{ }^{18}\right]$, was conducted with DARwin version 5.0. Discrimination analysis was performed by SPSS version 16.0 software.

\section{RESULTS AND DISCUSSION}

The total number of alleles and size of SSR markers varied from the ones originally reported, indicating that the source of the material tested differed from that of the previously characterized collections $\left[{ }^{14}\right]$. A total of 44 alleles were amplified from the 11 microsatellite loci in the 12 accessions. The number of alleles observed in the whole dataset ranged from 2 to 10 alleles per locus (Table-2). Moreover, four tested loci (Amor 46, Amor 22, Amor 36 and Amor 41) had PIC values greater than 0.30 , which is consistent with the results found for some of these loci by Pan et al. $\left[{ }^{14}\right]$. The highest value of average genetic diversity 
Genetic diversity analysis in Amorphophallus sp.

observed in the present study is 0.84 (Amor 36). The Amor 46 marker was highly polymorphic and had a high PIC value of 0.5 (Table-2). The estimates of RP were found to be the highest for the primer Amor 22 (3.50), followed by Amor 51 (3.16) and was lowest for the primer Amor 58 (0.17). The primers Amor 22, Amor 51, Amor 46, Amor 34, Amor 36 and Amor 43 also exhibited higher Resolving Power (3.50-1.50). The maximum MI was observed for the primer Amor 51 (3.89) followed by the Amor 36 (3.37), Amor
22 (3.06), Amor 57 (2.04), Amor 43 (1.51), Amor 46 (1.5), Amor 34 (1.16), Amor 41 (0.96), Amor 54 (0.79) and Amor 53 (0.77). The minimum MI was observed again for the primer Amor 58 (0.17). Further, the interrelationships between efficiency parameters were analyzed using Spearman rank correlation coefficient. The correlations between all parameters were highly significant (Table-3). This implied that all efficiency parameters are more or less equally important in assessing the efficiency of whole set of 11 SSR primers.

Table -3: Spearman rank correlation coefficient among the efficiency parameters of primers

\begin{tabular}{|l|l|l|l|l|}
\hline Parameters & PIC & MI & DI & RP \\
\hline PIC & 1.00 & $0.64^{*}$ & $0.75^{* *}$ & $0.74^{* *}$ \\
\hline MI & & 1.00 & $0.77^{* *}$ & $0.77^{* *}$ \\
\hline DI & & & 1.00 & $0.64^{*}$ \\
\hline RP & $*$ & & & 1.00 \\
\hline
\end{tabular}

“*” Significance at 5\% level: “**” significance at $1 \%$ level

Discrimination analysis was done for the identification of most efficient primer and effective parameter. It is clear from the discrimination analysis that most efficient parameter is MI (Figure-2), could identify most effective primer, Amor 51 (Figure-3) and also discriminate the least efficient primer.

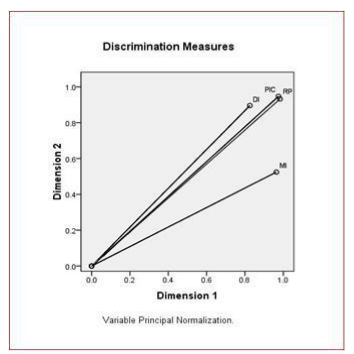

Figure-2: Discrimination measures of four efficiency parameters of 11 primers

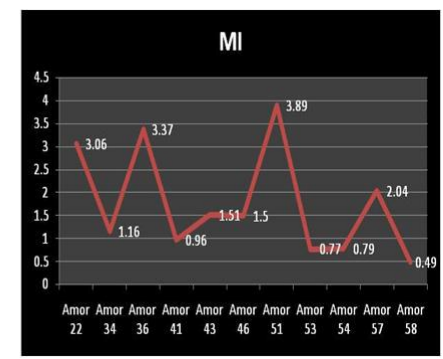

Figure-3: comparism of MI values and 11 primers

The PCoA plots (Figure-4) revealed three major clusters for elephant foot yam accessions for SSR markers. The proportion of variance explained by first three coordinates is $80.01 \%$.

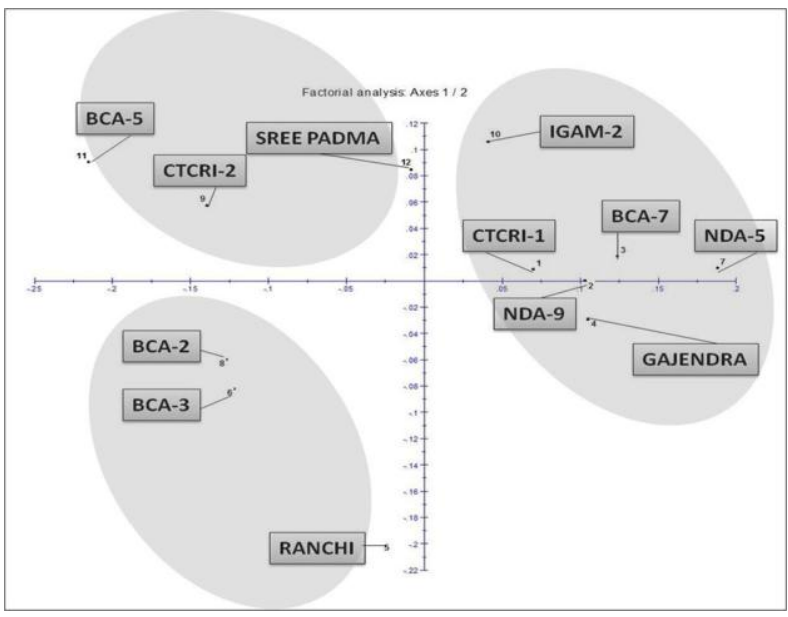

Figure-4: Two-dimensional representation of twelve genotypes according to PCoA analysis

On the basis of dendrogram three clusters wera formed (Figure-5). Cluster-I consist seven genotypes (NDA-5, IGAM-1, SREE PADMA, GAJENDRA, BCA-7, CTCRI-1 and NDA-9), clusters -II consists one genotypes (RANCHI) and cluster-III consist four genotypes (BCA-2, BCA-3, CTCRI-2 and BCA-5). In the cluster-I, NDA-9, CTCRI-1 and SREE PADMA, NDA-5 are closely related. Again, in cluster-III, BCA-2 and BCA-3 are closely related. This result was also supported by the PCoA analysis. 


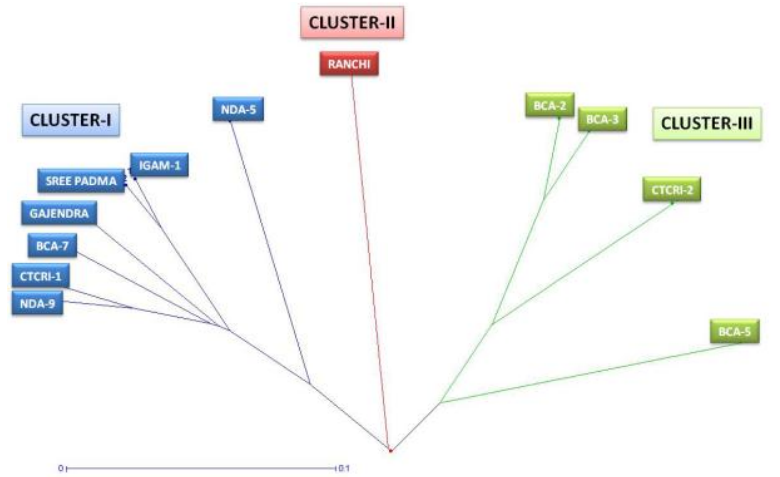

Figure-5: UPGMA cluster analysis of SSR data generated eleven primers for twelve cultivars of Elephant foot yam depicting patterns of genetic diversity

Overall at the genetic relatedness level SSR markers are more informative and it may be concluded on the basis of this study that for genetic diversity analysis with SSR markers were more effective.

\section{CONCLUSION}

A. paeoniifolius being essential for food security in many developing countries, it materializes necessity to broaden the genetic bases to facilitate farmers' varietal portfolios adaptation to climatic changes. But, there is no sufficient molecular marker for characterization and detection of genetic diversity for this crop. The present study contributes fundamental information for the implementation of appropriate conservation plans and breeding programs for elephant foot yam genetic resources. Thirteen of SSR markers was developed from the genomic sequences of A. konjac and applied in genetic diversity analyses of this species. Among these 13 SSR markers, 11 markers are cross-genus transferable to Amorphophallus spp. and can be useful for genetic studies in the araceae family. Present investigation showed that among these 13 primers 11 primers are suitable for the detection of genetic diversity in A. paeoniifolius and finally, it is found that Amor 51 is the most efficient SSR marker.

\section{ACKNOWLEDGEMENTS}

We would like to thank Director of Research, BCKV for his help and suggestions. This study was supported by grants from the AICRP on Tuber Crops, BCKV.

\section{REFERENCE}

1. Kurniawan A, Wibawa IPAH, Adjie B. Species diversity of Amorphophallus (Araceae) in Bali and Lombok with attention to genetic study in $A$. paeoniifolius (Dennst.) Nicolson. Biodiversitas. 2011; 12 (1) : 7-11.

2.W, Ittenbach S. Everything you always wanted to know about Amorphophallus, but were afraid to stick your nose into. Aroideana. 1996; 19: 7-131.

3. Arvill A, Bodin L. Effect of short-term ingestion of Konjac glucomannan on serum cholesterol in healthy men. Am J Clin Nutr. 1995; 61(3): 585-589.

4. Sood N, Baker WL, Coleman CI. Effect of glucomannan on plasma lipid and glucose concentrations, body weight, and blood pressure systematic review and meta-analysis. Am J Clin Nutr. 2008; 88(4): 1167-1175.

5. Jyoti DV, Sarman A, Madhrani N. Biochemical, Organoleptic and Antimicrobial Assessment of Elephant Foot Yam (Amorphophallus paeoniifolius). IOSR-JESTFT.2015; 9(5): 7-10.

6. Sugiyama N, Santosa E. Edible Amorphophallus in Indonesiapotential crops in agroforestry. Gadjah Mada University Press. Yogyakarta. [Indonesia]. 2008.

7. Singh A, Wadhwa N. A Review on Multiple Potential of Aroid: Amorphophallus paeoniifolius. Int J Pharm Sci Rev Res.2014; 24(1): 55-60.

8. Belaj A, Satovic Z, Cipriani G, Baldoni L, Testolin R, Rallo L, Trujillo I. Comparative study of the discriminating capacity of RAPD, AFLP and SSR markers and of their effectiveness in establishing genetic relationships in olive. Theor Appl Genet. 2003; 107(4): 736-744.

9. Song Z, Xu X, Wang B, Chen J, Lu BR. Genetic diversity in the northernmost Oryza rufipogon populations estimated by SSR markers. Theor Appl Genet. 2003; 107(8): 1492-1499.

10. Folkertsma RT, Rattunde HFW, Chandra S, Raju GS, Hash CT. The pattern of genetic diversity of Guinea-race Sorghum bicolor (L.) Moench landraces as revealed with SSR markers. Theor Appl Genet. 2005; 111(3): 399-409.

11. Barkley NA, Roose ML, Krueger RR, Federici CT. Assessing genetic diversity and population structure in a citrus germplasm collection utilizing simple sequence repeat markers (SSRs). Theor Appl Genet. 2006; 112(8): 1519-1531.

12. Hao C, Zhang X, Wang L, Dong Y, Shang X, Jia J. Genetic diversity and core collection evaluations in common wheat germplasm from the Northwestern Spring Wheat Region in China. Mol Breeding. 2006; 17(1): 69-77. 
Genetic diversity analysis in Amorphophallus sp.

13. Doyle JJ, Doyle JL. Isolation of plant DNA from fresh tissue. Focus. 1990; 12: 13-15.

14. Pan C, You Y N, Diao Y, Hu ZL, Chen JM, Isolation and characterization of microsatellite loci for the herbaceous tuber crop. Amorphophallus konjac (Araceae). Genetics and Molecular Research. 2012; 11 (4): 4617-4621.

15. Quintero VP, Lopez JLA, Colmenero AZ, Garcia NM, Colin CN, Bonilla JLS, Rangel MRA, Prom L. Genetic diversity of sweet sorghum germplasm in Mexico using AFLP and SSR markers. Pesq Agropec Bras Brasília. 2012; 47(8) : 1095-1102.

16. Sokal RR, Rahlf FJ. Biometry, $3^{\text {rd }}$ edn. 1995; USA.

17. Saini M, Sing S, Hussain Z. Sikka VK. RAPD analysis in mungbean [Vigna radiate (L.) Wilczek.] II: A comparison of efficiency parameters of RAPD primers. Indian Journal of Biotechnology. 2010; 9: 276-282.

18. Nei M, Li WH. Mathematical model for studying genetic variation in terms of restriction endonucleases. Proceedings of the National Academy of Sciences of the United States of America. 1979; 76: 5269-5273.

19. Rohlf FJ. NTSYS-Pc. Numerical taxonomy and multivariate analysis system. Version 2.1. Setauket. Exeter Software. 2000; 44.

Received: January 15, 2016; Accepted: May11, 2016 